\title{
The Effect of Heavy Metals (Copper and Cadmium) on the Germination of Bell Pepper Seeds (Capsicum annuumL. var. Dariana Bac)
}

\author{
GABRIEL ALIN IOSO ${ }^{1,2}$, VALENTIN NEDEFF ${ }^{1,3 *}$, ION SANDU ${ }^{4,5}$, TINA OANA CRISTEA ${ }^{2}$, MARIA PRISECARU ${ }^{6}$, \\ IOAN GABRIEL SANDU5,7* \\ ${ }^{1}$ Vasile Alecsandri University of Bacau, Department of Doctoral School, 157 Marasesti Str., 600115, Bacau, Romania \\ ${ }^{2}$ Vegetable Research and Development Station Bacau, 220 Calea Barladului, 600388, Bacau, Romania \\ ${ }^{3}$ Gheorghe Ionescu Sisesti Academy of Agricultural an Forest Sciences, 61 Marasti Str., 011464, Bucharest, Romania \\ ${ }^{4}$ Alexandru Ioan Cuza University of lasi, Arheoinvest Interdisciplinary Platform, Scientific Investigation Laboratory, 11 Carol I \\ Blvd., 700506 lasi, Romania \\ ${ }^{5}$ Romanian Inventors Forum, 3 Sf. Petru Movila Str., Bloc L11, III/3, 700089, Iasi, Romania \\ Vasile Alecsandri University of Bacau, Faculty of Biology, 157, Marasesti Str., 600115, Bacau, Romania \\ ${ }^{7}$ Gheorghe Asachi Technical University of lasi, Materials Science and Engineering Faculty, 53A D Mangeron Blvd., 700050, lasi, \\ Romania
}

\begin{abstract}
Bell pepper seeds (Capsicum annum L. var Dariana Bac), variety patented by Vegetable Research and Development Station Bacau, were germinated on filter paper (Whatman No. 1) moistened with a range of solutions in different concentrations of Copper (20, 100, 250 'i 500 mg/kg soil) and Cadmium (1, 3, 5, 10 mg/ $\mathrm{kg}$ soil). The solutions used are standard solutions of $\mathrm{Cu}$ and $\mathrm{Cd}\left(1 \mathrm{mg} / \mathrm{mL}\right.$ in $\left.5 \% \mathrm{HNO}_{3}\right)$. After 9 days the following indices were calculated: final germination percentage (FGP), mean germination time (MGT), germination index (GI), coefficient of velocity of germination (CVG) and germination rate index (GRI). The variety of bell pepper Dariana Bac responded differently to different concentrations of the studied heavy metals, having an average germination percentage of $76.5 \%$ on variants treated with standard $C d$ solution and an average germination percentage of only $29.4 \%$ on variants tested with $\mathrm{Cu}$ standard solution. Also, a decrease in the germination rate was observed with the increase of the concentration of $\mathrm{Cu}$.
\end{abstract}

Keywords: bell pepper, Copper, Cadmium, fitotoxicity, heavy metal stress, seed germination

Pepper (Capsicum annuum L.) is a plant of culture that prefers a warm climate. For pepper seeds to germinate, an optimal temperature of $25-27^{\circ} \mathrm{C}$ [1-3] is required. Among the vegetable species, it occupies an important place with numerous uses [1,2]. The fruits of peppers have a great importance because they can be consumed both fresh and preserved [1]. They contain a number of bioactive compounds and essential nutrients and it is also capable of accumulating heavy metals (HM) from contaminated soils [4].

Due to the intensification of various anthropogenic activities in recent decades (urbanization, industrialization, etc.), natural resources, especially soil and water resources, are polluted with various persistent organic and inorganic contaminants [5-22]. Among these, heavy metals (HM) are [4] classified as main soil contaminants [23]. In the recent years, contamination of agricultural land by HM has increased due to anthropogenic activities [23], and as they are easily absorbed by plants [23, 24], can pose a serious threat to human health. However certain $\mathrm{HM}$, such as iron (Fe), copper (Cu), manganese ( $\mathrm{Mn})$, zinc ( $\mathrm{Zn})$, nickel ( $\mathrm{Ni}$ ), and molybdenum (Mo) are considered to be micronutrients for plants, but also minerals required in the diet of humans and animals [23-25]. On the other hand, some of the $\mathrm{HM}$, such as cadmium $(\mathrm{Cd})$, mercury $(\mathrm{Hg})$, lead $(\mathrm{Pb})$, arsenic $(\mathrm{As})$, tin $(\mathrm{Sn})$, silver $(\mathrm{Ag})$, bismuth (Bi), chromium ( $\mathrm{Cr}$ ), are highly toxic to biological systems and they accumulate easily in living organisms [23].

It is known the benefits of copper ( $\mathrm{Cu}$ ) which is an essential element for plant growth and development [4,
23-26]. The largest source of $\mathrm{Cu}$ from the soil comes from industrial and agricultural waste [27]. However, the excessive availability of copper generates toxic effects in plants and can lead to a decrease in seed germination [28].

Excess of $C d$ in soils inhibits seed germination and root growth [29]. In many plants $\mathrm{Cd}$ is easily taken over by the root and transported to the shoots, in which case they can penetrate the food chain [4]. Most plants are sensitive to high concentrations of $C d$, which can lead to symptoms of phytotoxicity, such as plant growth inhibition, chlorosis, imbalance in absorption and distribution of macronutrients and ultimately plant death [30-33]. However, in different studies, the germination rate and index, root length and dry weight did not show a significant $(P<0.05)$ difference under low $\mathrm{Cd}$ concentrations ( 0 and $50 \mu \mathrm{mol} / \mathrm{L}$ ) [34].

Because toxicity is not only influenced by concentration, but also on the stage of plant development, the present paper focuses on the effect of heavy metals (copper and cadmium) on the germination of bell pepper seeds at an optimum germination temperature of $25^{\circ} \mathrm{C}$. In order to determine if there are any performance differences related to the germination of bell pepper seeds var. Dariana Bac in close dependence with the presence of $\mathrm{Cu}$ and $\mathrm{Cd}$ in the environment, 10 experimental variants were tested. The results were compared with the control variant - V5, in which the seeds were germinated on filter paper moistened only with distilled water. 


\section{Experimental part}

\section{Materials and methods}

The experiment was conducted in the laboratory of Biotechnologies-In Vitro Culturesfrom Vegetable Research and Development Station Bacau. In the experiment, a single genotype of bell pepper was used (Capsicum annuum var. Dariana Bac.) patented by Vegetable Research and Development Station Bacau. It's an early variety, with a vegetation period of 120 days until fruiting. The plant has medium vigor. Port $50 \%$ erect, $50 \%$ horizontal. Color - yellow with green hues attechnological maturity and bright red at physiological maturity. Shape trapezoidal in longitudinal section. Length - 9.5-11.5 cm, diameter - 7.5-8 cm, number of lobes - 3-4, pulp thickness - 7.5-8.5 mm, average fruit weight 80-120 g [35].

The experimental variants analyzed in the present research study are represented by different concentrations of $\mathrm{Cu}$ and $\mathrm{Cd}$ : $\mathrm{V} 1=20 \mathrm{mg} \mathrm{Cu}, \mathrm{V} 2=100 \mathrm{mg} \mathrm{Cu}, \mathrm{V} 3=250$ $\mathrm{mg} \mathrm{Cu}, \mathrm{V} 4=500 \mathrm{mg} \mathrm{Cu}, \mathrm{V} 5=$ Control - distilled water, V6 $=1 \mathrm{mg} \mathrm{Cd}, \mathrm{V} 7=3 \mathrm{mgCd}, \mathrm{V} 8=5 \mathrm{mg} \mathrm{Cd}, \mathrm{V} 9=10 \mathrm{mgCd}$ and $\mathrm{V} 10=500 \mathrm{mg} \mathrm{Cu}+10 \mathrm{mg} \mathrm{Cd}$. The values of the solutions of $\mathrm{Cd}$ and $\mathrm{Cu}$ were corelated with the values established in Order no. 756/3 November 1997 with regard to traces of chemical elements in the soil, reported as $\mathrm{mg}$ per $\mathrm{kg}$ soil and calculated for $50 \mathrm{~g}$ aqueous solution from standard solutions of $\mathrm{Cu}$ and $\mathrm{Cd}$ (Table 1 ).

For the experiment standard solutions of $\mathrm{Cu}$ and $\mathrm{Cd}(1$ $\mathrm{mg} / \mathrm{mL}$ in $5 \% \mathrm{HNO}_{3}$ ) were used. Seed germination was tested in laboratory conditions, on moistened filter paper (Whatman No. 1). In each Petri dish (90 $\mathrm{mm}$ in diameter) 30 pepper seeds were placed. The seeds were sow randomly under controlled temperature and light conditions in the Sanyo vegetation chamber (Fig. 1). Seeds were considered germinated when the root was visible (Fig. 2).

About $10 \mathrm{~mL}$ of solution of $\mathrm{Cu}$, respectively $\mathrm{Cd}$ have been added to ensure the humidity necessary to germinate the seeds of bell pepper. Distilled water was used for the control variant. In this study we also investigated the interaction

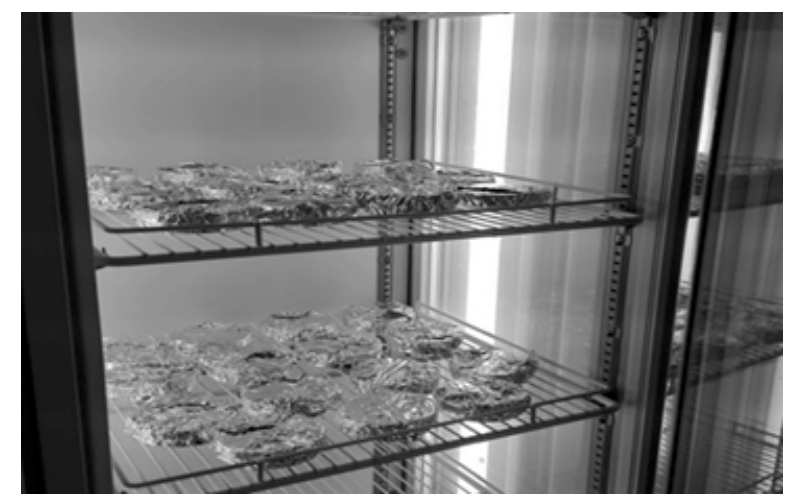

Fig. 1. Bell pepper seeds var. Dariana Bac in the Sanyo vegetation room

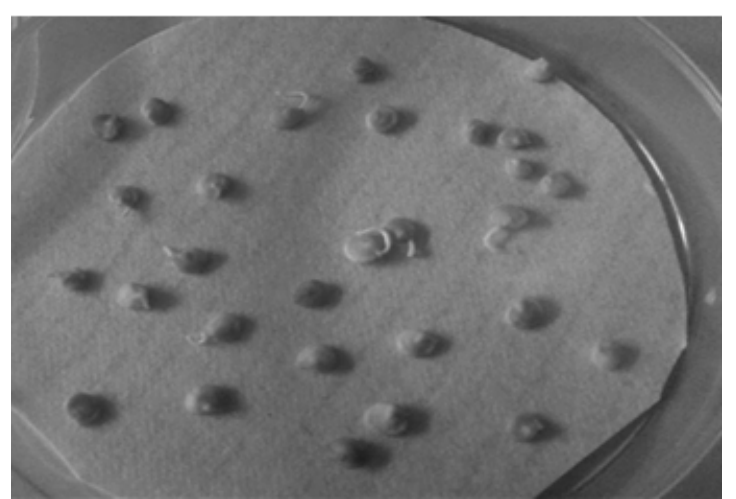

Fig. 2. Germination of bell pepper seeds var. Dariana Bac

between $\mathrm{Cu}$ and $\mathrm{Cd}$, in order to determine, the effect that these HM can have on the studied bell pepper seeds. In variant 10 , above the maximum concentration of $\mathrm{Cu}(500$ $\mathrm{mg} / \mathrm{kg}$ soil) was added the maximum concentration of $\mathrm{Cd}$ (10 mg/kg soil) to observe the synergistic effect of the two heavy metals. Each experimental variant was performed in three repetitions.

After the appearance of the cotyledons, the culture of bell pepper, were passed in photoperiod conditions of $16 \mathrm{~h}$ light - $8 \mathrm{~h}$ dark, at a temperature of $25^{\circ} \mathrm{C}$.

For the calculation of the germination indices, the germinated seeds were counted every two days and the results were noted in the observation book. At the end of the experiment, the following indices were calculated as follows:

Final germination percentage (FGP)

$F G P=$ final number of seeds germinated in a seed lot $x 100$

The higher the FGP value is, the higher is the germination of seeds [12, 23, 25-27].

$$
M G T=\frac{\sum f * x}{\sum f}
$$

where: $\mathbf{f}$ represents the seeds germinated on the day $\mathbf{x}$ $[12,23]$.

Germination index (GI):

$$
G I=\frac{\sum T_{i} N_{i}}{S}
$$

where: $\mathbf{T i}$ represents the number of days after the seed has been put into contact with the chemical for analyze, $\mathrm{Ni}$ represents the number of seeds germinated on the day $i$ and $S$ represents the total number of seeds per repetition [36-40]. The appearance of the radicle is considered as an index of the germinal faculty [37].

Coefficient of velocity of germination (CVG):

\begin{tabular}{|c|c|c|c|c|}
\hline $\begin{array}{c}\text { Chemical } \\
\text { elements }\end{array}$ & $\begin{array}{c}\text { Traces of elements } \\
\text { in soil }\end{array}$ & $\begin{array}{c}\text { Soil concentration } \\
(\mathrm{mg} / \mathrm{kg})\end{array}$ & $\begin{array}{c}\text { Concentration tested } \\
\text { in experiments } \\
(\mathrm{mg} / 50 \mathrm{~mL})\end{array}$ & $\begin{array}{c}\mathrm{H}_{2} \mathrm{O} \text { volume for the } \\
\text { test solution }(\mathrm{mL})\end{array}$ \\
\hline \multirow{4}{*}{$\mathrm{Cu}$} & Normal value & 20 & 1 & 49.00 \\
\cline { 2 - 5 } & Alert threshold & 100 & 5 & 45.00 \\
\cline { 2 - 5 } & $\begin{array}{c}\text { Intervention } \\
\text { threshold }\end{array}$ & 250 & 12.5 & 37.50 \\
\cline { 2 - 5 } & Normal value & 500 & 25 & 25.00 \\
\cline { 2 - 5 } $\mathrm{Cd}$ & Alert threshold & 1 & 0.05 & 49.95 \\
\cline { 2 - 5 } & Intervention & 3 & 0.15 & 49.85 \\
\cline { 2 - 5 } & threshold & 5 & 0.25 & 49.75 \\
\hline
\end{tabular}

Table 1

VARIANTS OF THE CU AND Cd SOLUTIONS USED IN THE EXPERIMENT 


$$
C V G=100 * \frac{\sum N i}{\sum N_{i} T_{i}}
$$

where: $\mathbf{N i}$ is the number of germinated seeds per day, and Ti number of days from the beginning of the experiment [36-41].

Germination rate index (GRI):

$$
G R I=G 1 / 1+G 2 / 2+\ldots G x / x
$$

where: $\mathbf{G 1}=$ percentage of germination $\times 100$ on the first day after sowing, $\mathbf{G 2}=$ percentage of germination $\times 100$ on the second day after sowing, $\mathbf{G} \mathbf{x}=$ percentage of germination $\times 100$ on the day $\boldsymbol{x}$ after sowing [41].

\section{Results and discussions}

This study shows a significant influence of the $\mathrm{HM}(\mathrm{Cu}$ and $C d$ ) on the bell pepper seeds (Capsicum annuum $L$. var. Dariana Bac) germination. Figure 3 shows that on the studied variants the highest germination rate is $82 \%$ on variant $\mathrm{V} 6$ ( $1 \mathrm{mg} \mathrm{Cd} / \mathrm{kg}$ soil) and the lowest is $0 \%$ on variant V4 (500 mg Cu/kg soil). Compared to V5, which is the control variant and has a FGP value of $74 \%$, variants treated with $\mathrm{Cd}(\mathrm{V} 6, \mathrm{~V} 7, \mathrm{~V} 8, \mathrm{~V} 9)$ have an average germination rate of $76.5 \%$, and seeds treated with solution of $\mathrm{Cu}(\mathrm{V} 1, \mathrm{~V} 2, \mathrm{~V} 3$, V4) have a lower average percentage of germination rate, only $29.4 \%$. The FGP value decreases with increasing concentration at variants treated with Cu solution. In the case of variant V10 (500 mg Cu/kg soil $+10 \mathrm{mg} \mathrm{Cd} / \mathrm{kg}$ soil) the presence of the maximum $\mathrm{Cd}$ concentration tested, resulted in a slightly increase of germination rate until $4 \%$ compared to V4, where the germination was completely inhibited by the presence of $\mathrm{Cu}$ in the highest concentration tested. FGP shows that the germination process of the seeds of bell pepper is inhibited by the increased concentrations of $\mathrm{Cu}$. Instead Cd didn't show an

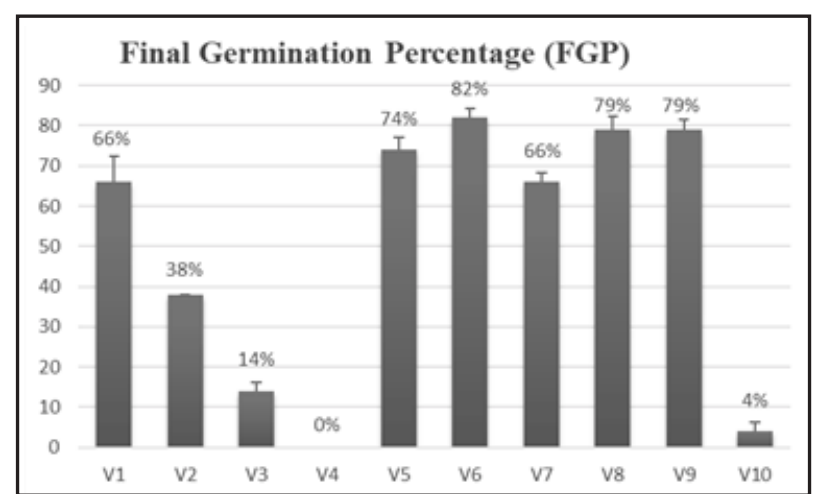

Fig. 3. Final germination percentage of bell pepper seeds (C. annuum L. var. Dariana Bac)

inhibitory effect over the germination, moreover the variant with $\mathrm{Cd}$ had a slightly increase when compared with the control variant (Fig. 3).

Mean germination time (MGT) it is a measure of the rate of germination and the temporal spread of germination [40]. Thus, it was determined the number of seeds germinated in first day and the total number of seeds germinated on the ninth day, taking in consideration the number of viable seeds germinated. On the second day after the start of the experiment, on none of the experimental variants germinated seeds were registered. This is also due to the fact that pepper seeds require a germination time of 9-11 days at an optimal germination temperature between $25-28^{\circ} \mathrm{C}[1,2]$. On the fourth day the seeds began to germinate both on the control variant V5 and on the variants treated with $\mathrm{Cd}$, and the highest MGT value is on $\mathrm{V} 9$ ( $10 \mathrm{mg} \mathrm{Cd} / \mathrm{kg}$ soil) - 1.73. Cu has the highest
MGT value in the fourth day on variant V1 $(20 \mathrm{mg} \mathrm{Cu} / \mathrm{kg}$ soil) - 1.37. An increase in the value of MGT was observed on the seeds of bell pepper in the seventh day in three of the variants treated with $\mathrm{Cd}$ (V6-3.18, V7-2.33, V8-2.95) but also in variant V2 (100 mg Cu/kg soil) - 1.94, with the highest MGT value registered during the experiment. V5 (control) shows the highest MGT value in the seventh day (2.56). On the ninth day the MGT value is constantly maintained at $\mathrm{V} 9$ (10 $\mathrm{mg} \mathrm{Cd} / \mathrm{kg}$ soil) - 1.9 , having a value very close to the fourth and seventh days. In the case of bell pepper seeds treated with $\mathrm{Cu}$ the value of the MGT index remains high at V1 (20 mg Cu/kg soil) - 1.37. As can be seen from figure 4, in the case of variants with $\mathrm{Cu}$ the MGT was higher on the seventh and ninth day as in the fase of $\mathrm{Cd}$ and control variant. However, the germination The mean of germination time (MGT)

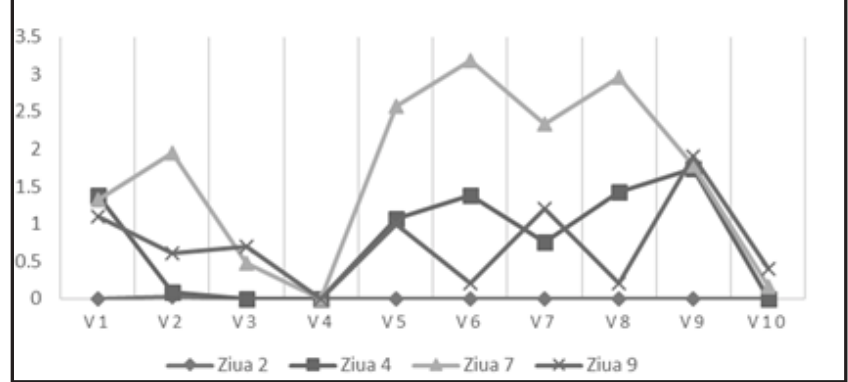

Fig. 4. Mean germination time for bell pepper seeds (C. annuum L. var. Dariana Bac)

of bell pepper seeds was much lower on the variants treated with $\mathrm{Cu}$ in all four days of observations.

Germination index (GI) reflects the germination speed of the seeds but also the vigor of the seedling by the appearance of the radicle. A low Gl expresses a low vitality of bell peppers seed germination [40], and this can be easily seen in the case of the seeds germinated on Cu solution concentrations (Fig. 5). The GI value decreases with increasing concentration. In the case of $\mathrm{Cd}$, the value of $\mathrm{Gl}$ increases for V6 (1 mg Cd/kg soil), -4.60, V8 ( $5 \mathrm{mg} \mathrm{Cd} / \mathrm{kg}$ soil) -4.55, and V9 ( $10 \mathrm{mg} \mathrm{Cd} / \mathrm{kg}$ soil) -5.04 , but it decreases in the case of the V7 ( $3 \mathrm{mg} \mathrm{Cd} / \mathrm{kg}$ soil) -3.28, compared to $\mathrm{Gl}$ from variant V5 (control) -3.94 . Seeds treated with $\mathrm{Cu}$ standard solution (V1-3.80, V2 -1.57, V3 -0.54 and V4 -0) express a low germination rate as opposed to treatments

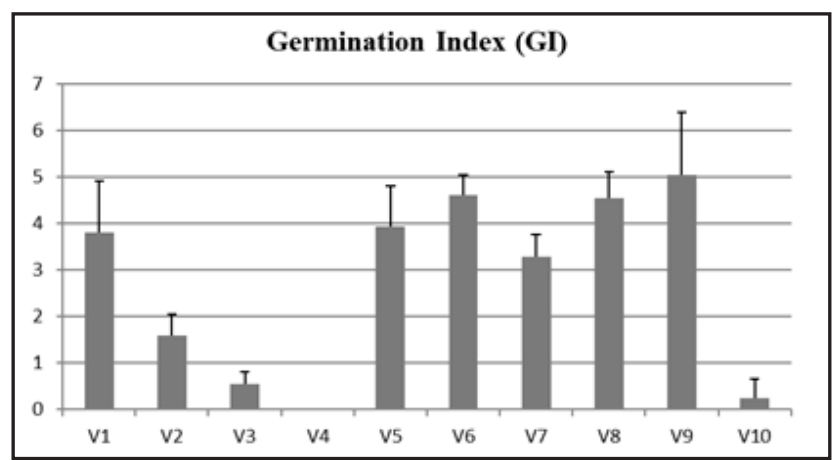

Fig. 5. Bell pepper seeds germination index (C. annuum L. var. Dariana Bac)

with $C d$ standard solution which express a high germination vitality of bell pepper seeds over time.

Coefficient of velocity of germination (CVG) gives us a clue regarding the rapidity of seed germination [30]. The CVG index increases when the number of germinated seeds increases and the time required for germination decreases [42]. Theoretically the highest possible CVG is $100 \%$ and this happens if all the seeds tested on one variant 
germinate on the same day [41, 42]. Bell pepper seeds did not have a CVG value greater than $50 \%$ on any of the tested variants. How ever, V6 (1 mg Cd/kg soil) has the highest CVG value (6.46\%) and is recorded on the seventh day. V9 ( $10 \mathrm{mg} \mathrm{Cd} / \mathrm{kg}$ soil) had the highest CVG value recorded on day four $(9.43 \%)$. This can mean a greater stimulation of germination and a shorter germination time for the bell pepper seeds sprouted on Cd. Seeds germinated on Cu solution have a higher CVG value on V1 ( $20 \mathrm{mg} \mathrm{Cu} / \mathrm{kg}$ soil) $-1.34 \%$ on the fourth day from the beginning of the experiment and in the seventh day on V2 (100 mg Cu/kg soil) $-2.28 \%$. However, we observed an inhibition for the bell pepper seeds germination tested on Cu standard solution and a longer germination time. The majority of the

coefficient of germination rate (CVG)

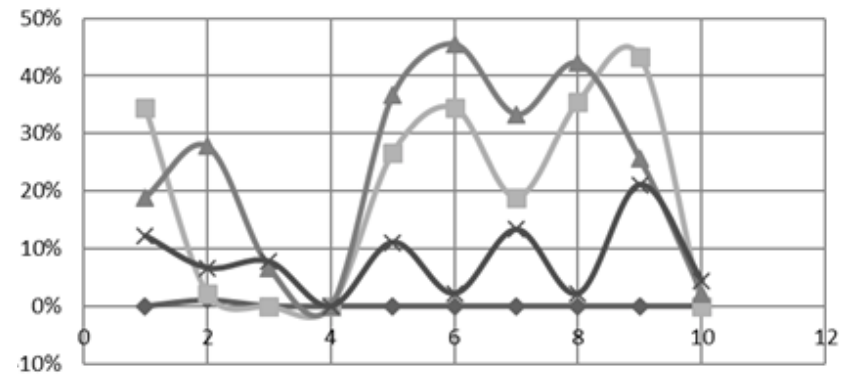

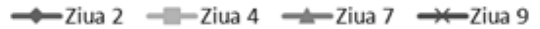

Fig. 6. Coefficient of germination rate for bell pepper seeds (C. annuum L. var. Dariana Bac)

seeds germinated on the seventh and ninth day from the beginning of experiment (Fig. 6).

High percentage values of germination rate index (GRI), indicates the higher and faster germination [43] for bell pepper seeds. We observe this in the variants where seeds were treated with $\mathrm{Cd}$ standard solution. V9 $(10 \mathrm{mg} \mathrm{Cd} / \mathrm{kg}$ soil) has the highest GRI average percentage (17\%) of all analyzed variants and V7 ( $3 \mathrm{mg} \mathrm{Cd} / \mathrm{kg}$ soil) has the lowest GRI average percentage (11\%) for the germinated seeds on the standard solution of $\mathrm{Cd}$. The average of the GRI index, of all the seeds germinated on the variants of $\mathrm{Cd}$ exceeds that of the seeds germinated on the variant V5 (control). However, in the case of Cu, V1 (20 mg Cu/kg soil) has an average GRI percentage equal with V5, but the small GRI percentages of the variants V2 (100 mg Cu/kg soil), V3 (250 mg Cu/kg soil) and V4 (500 mg Cu/kg soil) show that the germination of bell pepper seeds at these concentrations is low and slow (Fig. 7).

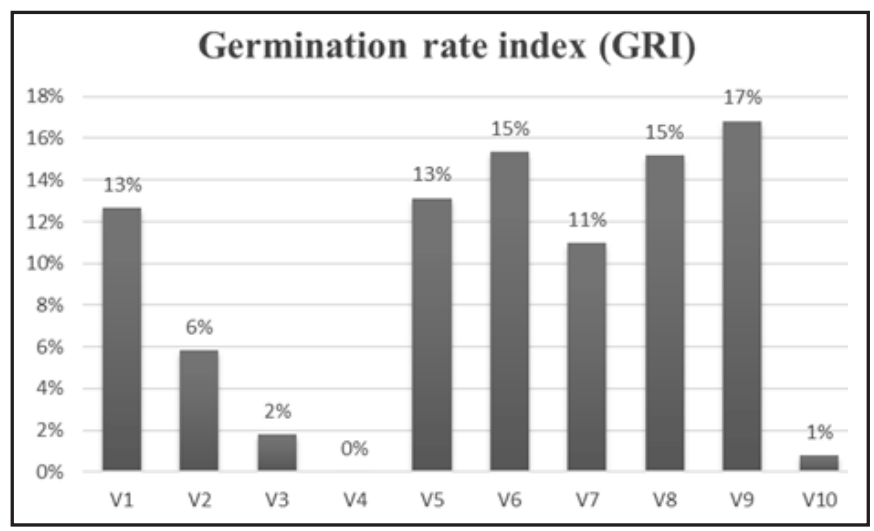

Fig. 7. Germination rate index at bell pepper seeds

(C. annuum L. var. Daiana Bac).

During the experiments a high rate of appearance of mold and bacteria was observed on the tested variants. The incidence of mold emergence on Cu variants in the case of seeds germinated was much higher than on the variants tested with $\mathrm{Cd}$, compared to the control variant, where the incidence of molds was zero. Which could mean that $\mathrm{Cu}$, not only inhibits, in high concentrations, the germination of pepper seeds, but also stimulates the appearance of mold. In order to validate this hypothesis, these aspects will be deepened in future studies on the influence of heavy metals on the different stages of germination, growth and development of plants.

\section{Conclusions}

The results presented in this paper show the toxic effects of $\mathrm{Cu}$ on bell pepper germination but also the stimulatory effects of $\mathrm{Cd}$. As it was observed on the studied variants, that the highest germination rate is $82 \%$ on the variant contaminated with $\mathrm{Cd}$ solution and the lowest rate of germination is $0 \%$ on the variant treated with Cu solution. Compared with V5, which represents the control variant, the variants treated with $\mathrm{Cd}(\mathrm{V} 6, \mathrm{~V} 7, \mathrm{~V} 8, \mathrm{~V} 9)$ have a higher germination percentage, and in the seeds treated with $\mathrm{Cu}$ solution (V1, V2, V3, V4) it is much smaller and decreases with the increase of Cu concentration. In the case of V10 ( $500 \mathrm{mg} \mathrm{Cu} / \mathrm{kg}$ soil $+10 \mathrm{mg} \mathrm{Cd} / \mathrm{kg}$ soil) the presence of the maximum $\mathrm{Cd}$ concentration tested, resulted in a slightly increase of germination rate until $4 \%$ compared to V4, where the germination was completely inhibited by the presence of $\mathrm{Cu}$ in the highest concentration tested.

There was an increase in the MGT value in the seeds of bell peppers on the seventh and ninth days on the variants treated with $\mathrm{Cd}$. Also, on the seventh and ninth day, the MGT values also increased in the case of the variants treated with $\mathrm{Cu}$. However, the germination of pepper seeds was much lower on the variants treated with Cu in all four days of observations.

The $\mathrm{GI}$ value decreases with increasing concentration in the case of Cu. But the Gl values of Cd increase in V6 (1 $\mathrm{mg} \mathrm{Cd} / \mathrm{kg}$ soil), V8 (5 mg Cd/kg soil) and $\mathrm{V} 9$ (10 $\mathrm{mg} \mathrm{Cd} / \mathrm{kg}$ soil).

Bell pepper seeds did not have a CVG value greater than $50 \%$ on any of the tested variants. However, $\mathrm{V} 6(1 \mathrm{mg} \mathrm{Cd} /$ $\mathrm{kg}$ soil) has the highest CVG value and is recorded on the seventh day. V9 (10 mg Cd/kg soil) has the highest CVG value recorded on day four. This express a greater stimulation of germination and a shorter germination time in the seeds of sprouted peppers on Cd.

In the seeds treated with $\mathrm{Cd}$ solution we observe the high percentage of GRI values, which indicates the higher and faster germination of bell pepper seeds on the variants treated with $\mathrm{Cd}$ compared to the variants treated with $\mathrm{Cu}$.

\section{References}

1.CIOFU, R., Vegetable treaty, Ceres Publishing house, Bucharest, 2004, p. 646.

2.CALIN, M., Guide for growing vegetables in organic farming, Alma Mater Publishing house, 2010, p. 136.

3.DEMIR, I., ERMIS, S., MAVI, K., MATTHEWS, S., Mean germination time of pepper seed lots (Capsicum annuum L.) predicts size and uniformity of seedlings in germination tests and transplant modules. Seed Science and Technology, 36, no 1, 2008, p. 21.

4.IOSOB, G. A., NEDEFF, V., SANDU, I., PRISECARU, M., CRISTEA, T.O., Study of Phytotoxic effects of $\mathrm{Cu}^{2+}$ and $\mathrm{Cd}^{2+}$ on Seed Germination and Chlorophyll Pigments Content to the Bell Pepper, Rev. Chim. (Bucharest), 70, no. 4, 2019, p. 1416.

5.ONDRASEK, G., RENGEL, Z., ROMIC, D., Humic acids decrease uptake and distribution of trace metals, but not the growth of radish exposed to cadmium toxicity. Ecotoxicologyand Environmental Safety, 151, 2018, p. 55.

6.CHITIMUS, A. D., RADU, C., NEDEFF, V., MOSNEGUTU, E., BARSAN, $N$., Studies and researches on typha latifolia's (bulrush) absorption capacity of heavy metals from the soil, Scientific Study \& Research. 
Chemistry \& Chemical Engineering, Biotechnology, Food Industry, 17, no. 4, 2016, p. 381.

7.GOLDAN, E., NEDEFF, V., SANDU, I.G., MOSNEGUTU, E., PANAINTE, $M$. . Study of greenhouse use of biohazard wastewater and manure compost, Rev. Chim. (Bucharest), 70, no. 1, 2019, p. 169.

8.RADU, C., CHITIMUS, D., TURCU, M., ARDELEANU, G., BELCIU, M., Environmental Engineering and Management J ournal, 13, no. 7, 2014, p. 1687.

9.CHITIMUS, A.D., RADU, C., NEDEFF, V., MOSNEGUTU, E., BARSAN, N., Scientific Study \& Research. Chemistry \& Chemical Engineering, Biotechnology, Food Industry, 17, no. 4, 2016, p. 381.

10.MUSCALU (PLESCAN), O.M., NEDEFF, V., CHITIMUS, A.D., SANDU, I.G., PARTAL, E., MOSNEGUTU, E., SANDU, I., RUSU, D.I., Rev. Chim. (Bucharest), 69, no. 11, 2018, p. 3016.

11.RADU, C., NEDEFF, V., CHITIMUS, A.D., J ournal of Engineering Studies \& Research, 19, no. 2, 2013, p. 89.

12.CHITIMUS, A.D., BARSAN, N., NEDEFF, V., MOSNEGUTU, E., MUSCALU (PLESCAN), O., Studies and research concerning the influence of liquid pollutants' leaching speed in the soil on the process of cleaning and self-cleaning, 17th International Multidisciplinary Scientific GeoConference SGEM, 17, no. 51, 2017, p. 859.

13.MUSCALU (PLESCAN), O.M., NEDEFF, V., CHITIMUS, A.D., PARTAL, E., BARSAN, N., RUSU, I.D., Rev. Chim. (Bucharest), 70, 2, 2019, p. 536.

14.MUSCALU (PLESCAN), O.M., NEDEFF, V., SANDU, I.G., PARTAL, E., MOSNEGUTU, E., BARSAN, N., SANDU, I., RUSU, D., Rev. Chim. (Bucharest), 70, no. 5, 2019, p. 1726.

15.GOLDAN, E., NEDEFF, V., SANDU, I., BARSAN, N., MOSNEGUTU, E., PANAINTE, M., Rev. Chim. (Bucharest), 70, no. 6, 2019 p. 2192.

16.GOLDAN, E., NEDEFF, V., BARSAN, N., MOSNEGUTU, E., SANDU, A.V., PANAINTE, M., Rev. Chim. (Bucharest), 70, no. 3, 2019, p. 809. 17. BOCIORT, D., GHERASIMESCU, C., BERARIU, R., BUTNARU, R., BRANZILA, M., SANDU, I., Rev. Chim. (Bucharest), 63, no. 11, 2012, p. 1152.

18.PAPADATU, C.P., BORDEI, M., ROMANESCU, G., SANDU, I., Rev. Chim. (Bucharest), 67, no. 9, 2016, p. 1728.

19.LUPASCU, T., CIOBANU, M., BOTAN, V., SANDU, I.G., DRAGALIN, I., MITINA, T., SANDU, I., Rev. Chim. (Bucharest), 69, no. 11, 2018, p. 3082.

20.MUSCALU, O.M., NEDEFF, V., CHITIMUS, A.D., SANDU, I.G., PARTAL, E., MOSNEGUTU, E., SANDU, I., RUSU, D.I., Rev. Chim. (Bucharest), 69, no. 11, 2018, p. 4006.

21.IACOBAN, C., RISCA, I.M., ROIBU, C., CIORNEA, E.T., NECULA, R., ILIEVA, D., SANDU, I., DROCHIOIU, G., Rev. Chim. (Bucharest), 70, no. 3, 2019, p. 753.

22.BODESCU, D., UNGUREANU, G., MORARU, R.A., SANDU, I.G., BEJ INARIU, C., Rev. Chim. (Bucharest), 69, no. 8, 2018, p. 2150. 23.PIOTTO, F.A., CARVALHO, M.E.A., SOUZA, L.A., RABÊLO, F.H.S., FRANCO, M.R., BATAGIN-PIOTTO, K.D., AZEVEDO, R.A., Environmental Science and Pollution Research, 25, no. 27, 2018, p. 27535.

24.APOSTU, M., TANTARU, G., VIERIU, M., PANAINTE, A.D., BIBIRE, N., AGOROAEI, L., Rev. Chim.(Bucharest), 68, no. 4, 2017, p. 683.
25.HIPPLER, F.W.R., PETENA, G., BOARETTO, R.M., QUAGGIO, J.A., AZEVEDO, R.A., MATTOS-J R, D., Environ. Sci. Pollut. Res., 25, 2018, p. 13134.

26.FERREIRA, P.A.A., LOURENZI, C.R., TIECHER, T., TIECHER, T.L., RICACHENEVSKY, F.K., BRUNETTO, G., GIACHINI, A.J., SOARES, C.R.F.S., Physiological, biochemical changes, and phytotoxicity remediation in agricultural plant species cultivated in soils contaminated with Copper and Zinc, Plants under metal and metalloid stress, Springer Publishing House, Singapore, 2018, p. 29.

27.YRUELA, I., Funct. Plant Biol., 36, 2009, p. 409.

28.MORAVCOVA, S., TUUMA, J., DUCAIOVA, Z. K., WALIGORSKI, P., KULA, M., SAJA, D.,SLOMKA, A., BABA, W., LIBIK-KONIECZNY, M., Plant Physiology and Biochemistry, 122, 2018, p 19.

29.LIU, D., JIANG, W., GAO, X., Biologia Plantarum, 47, 2003, p. 79. 30.SHAH, K., KUMAR, R. G., VERMA, S., DUBEY, R., Plant Science, 161, no. 6, 2001, p. 1135.

31.CHITIMUS, A.D., COCHIORCA, A., NEDEFF, V., BARSAN, N., MUSCALU, 0 ., Studies and research on phragmites australis' (common reed) absorption capacity of heavy metals from the soil in Roman City, Romania, Proceeding of the International Multidisciplinary Scientific Geo Conference Surveying Geologyand Mining Ecology Management, SGEM, 18, 2018, p. 671.

32.GILL, S.S., KHAN, N.A., TUTEJ A, N., Plant Science, 182, 2012, p. 112. 33.CHOUDHARY, R.C., KUMARASWAMY, R.V., KUMARI, S., PAL, A., RALIYA, R., BISWAS, P., SAHARAN, V., Synthesis, characterization, and application of chitosan nanomaterials loaded with zinc and copper for plant growth and protection. Nanotechnology, Springer Nature Singapore Pte Ltd, 2017, p. 227.

34.ZHANG, X., LI, C., NAN, Z., Sci. China Life Sci., 55, no. 9, 2012, p. 793.

35.***https://www.madr.ro/docs/cercetare/Rezultate_ activitate de_cercetare/SCDL_BACAU.pdf, 2018,

36.ALSAEEDI, A., EL-RAMADY, H., ALSHAAL, T., EL-GARAWANI, M., ELHAWAT, N., AL-OTAIBI, A., Plant Physiology and Biochemistry, 125, 2018, p. 164.

37.ZHOU, H., MENG, H., ZHAO, L., SHEN, Y., HOU, Y., CHENG, H., SONG, L., Bioresource Technology, 258, 2018, p. 279.

38.BAPI, G., KUMAR, D.A., DEBADRITO, D., VISHAMBHAR, K.D., ANKITA, P., Research J ournal of Chemistry and Environment, 22, 2018, p. 34.

39.LU, C.M., ZHANG, C.Y., WEN, J.Q., WU, G.R., TAO, M.X., Soybean Sci., 21, no. 3, 2002, p. 168.

40.SIDDIQUI, M.H., AL-WHAIBI, M.H., Saudi Journal of Biological Sciences, 21, no 1, 2014, p. 13.

41.KADER, M.A., J ournal and Proceedings of the Royal Society of New South Wales, 138, 2005, p. 65.

42.MOGHADAM, P.A., ALAEI, Y., Pharmacology and Life Sciences, 3, no 5, 2014, p. 5.

43.SHINDE, S., PARALIKAR, P., INGLE, A.P., RAI, M, Arabian J ournal of Chemistry, 2018, DOI: 10.1016/j.arabjc.2018.10.001.

Manuscript received: 21.05 .2019 